\title{
16
}

\section{THE AUSTRALIAN FEDERAL RESPONSE TO THE COVID-19 CRISIS}

\section{Momentary success or enduring reform?}

\author{
Nicholas Aroney and Michael Boyce
}

\subsection{Introduction}

The Commonwealth of Australia is a federation of six constituent states and two self-governing territories. With an area of almost 7.7 million $\mathrm{km}^{2}$, it is the world's sixth largest country and the only nation-state occupying an entire continent. With a total population of just over 25 million, Australia is one of the most sparsely populated countries in the world; however, it is also one of the most urbanised, with more than half of its population living in five urban centres of more than 1 million persons. The Australian states and territories differ vastly in land area and population. The largest state, Western Australia, is more than 2.2 million $\mathrm{km}^{2}$, while the smallest, Tasmania, is less than $70,000 \mathrm{~km}^{2}$; the most populous state, New South Wales (NSW), has more than 7.7 million people, while the least populous, Tasmania, has a little over 520,000 . Australia has a highly developed economy, with one of the largest gross domestic products (GDPs) per person in the world and with Australians enjoying an average life expectancy of more than 83 years - also among the highest in the world.

In 2020, Australia experienced two waves of Covid-19 cases, the first in March-April and the second in July-August. At the time of writing (November 2020), a total of more than 9 million Covid-19 tests had been administered, 27,668 cases confirmed, and 907 deaths recorded, 819 of which were in the State of Victoria. More than 93 per cent of Covid-19-related deaths were among persons older than 70, with 685 of these associated with aged-care facilities and 655 occurring in Victoria (Department of Health 2020c; Pagone and Briggs 2020: $2,15)$. Cases and deaths were concentrated in densely populated urban centres; by contrast, there were many regional and remote communities that experienced very few or no cases. 
The Australian policy response was coordinated between the Commonwealth, states, territories, and local government through a newly formed 'National Cabinet' consisting of the Prime Minister, the Premiers of the states and the First Ministers of the territories, supported by an array of health officers and expert advisers. This response was built on legislative frameworks and policy plans that were already in place to deal with national emergencies, including pandemics. Collectively, the implemented measures were remarkably successful in containing the virus despite occasional but serious administrative failures.

The main tension points concerned differences in policy goals (containment versus eradication) and the appropriate policy settings to achieve these goals (e.g., strict lockdowns and state border closures), with differences in political ideology as well as variations in local conditions driving disagreements between right-ofcentre Liberal-National Party coalition governments at a Commonwealth level and in NSW, South Australia and Tasmania, and left-of-centre Labour Party governments in Victoria, Queensland, Western Australia, and the two territories. Despite these tensions, the federal system has worked relatively well overall, enabling a nationally coordinated approach with localised variations in governmental response, at least at a state and territory level, though not always in a manner well adjusted to the needs and circumstances of smaller local communities, especially in remote regions.

\subsection{The federal constitutional and legislative framework}

Under the Australian Constitution, the states continue to exercise the general legislative, executive, and judicial powers they possessed prior to federation, while the Commonwealth is vested with overriding legislative powers over a range of specific topics. These powers enable the Commonwealth to control Australia's national borders, such as by restricting entry of persons into the country and imposing quarantine requirements. In most other respects, governmental responses to the Covid-19 pandemic were implemented by the states and territories, including management of hospitals and intensive care facilities, restrictions on personal movement and interaction, and imposition of social distancing and lockdown requirements. The powers of both the Commonwealth and the states are subject, however, to a constitutional requirement that 'trade, commerce and intercourse' among the states be 'absolutely free', potentially restricting their ability to control personal movement across state borders.

The Commonwealth, states, and territories each have their own democratically elected legislatures and executive governments responsible to those legislatures. They also have independent taxing and spending powers, except that the Commonwealth has a constitutional monopoly over taxes on goods and has in effect monopolised taxes on individual and corporate income. Consequently, the states are dependent on the Commonwealth for approximately half of their revenues and the Commonwealth has the capacity to make conditional grants to the states that require them to pursue particular policies and meet operational 
benchmarks. The Commonwealth also has much greater capacity to provide general financial support and welfare benefits by way of income supplementation and economic stimulus.

Local governments, on the other hand, are creatures of the states and have had relatively limited capacity to develop policies responsive to the pandemic. Nonetheless, they initiated measures to support local communities and businesses, such as through relief from council rates, fees and other taxes, and engaged with state and territory governments in developing and implementing coordinated government responses.

The constitutional settings of the Australian federal system enable three principal modes of governmental response: (1) independent policy-making by the Commonwealth, states, and territories, each exercising autonomous powers of governance within its particular jurisdiction; (2) coordinated policy-making based on agreement among the Commonwealth, state, and territory governments, each exercising its constitutional powers as mutually agreed; and (3) coercive policymaking by the Commonwealth using its overriding legislative powers and financial capacities to determine or shape the policies to be implemented by the states and territories. The extent to which each of these approaches is adopted in response to any emergent issue or problem has significant implications for the efficiency and effectiveness of the policy response. As Alan Fenna (2020: 1) has put it:

Federalism might have hindered an effective response to the crisis by creating obstacles to action or discoordination. On the other hand, it might have encouraged a proportional and appropriate response by opening the way to regionally varied measures and by mustering the greater wisdom of a more collective decision-making process.

\subsection{Preparedness for a national disaster: The institutional framework}

Prior to the emergence of the pandemic, the Commonwealth, states, and territories had enacted legislation authorising the use of emergency powers to respond to bio-security threats, such as by imposing quarantine requirements, restricting movement, controlling commerce, and prohibiting gatherings. These included the National Health Security Act of 2007, which establishes a national system of public health surveillance, and the Biosecurity Act of 2015, which facilitates management of biosecurity risks and emergencies. The Biosecurity Act gives the federal Health Minister expansive powers to issue directions and impose requirements to combat human biosecurity emergencies. Each state and territory also has its own disaster response and public health laws which authorise officials to declare a state of emergency and issue orders and directions to deal with natural disasters and public health emergencies.

The Commonwealth had also developed the Australian Health Management Plan for Pandemic Influenza (AHMPPI), which was used to guide Australia's 
response to the H1N1 pandemic in 2009 and was revised in 2014 and again in late 2019 (Department of Health 2019). More broadly, in 2011 the Council of Australian Governments (COAG) adopted a National Strategy for Disaster Resilience to support the development of coordinated policies at all levels of government for preventing, preparing for, responding to, and recovering from disasters of all kinds (Council of Australian Governments, 2011). Following Australia's adoption of the United Nations Sendai Framework for Disaster Risk Reduction 2015-2030, the country's policies also focused on preventing the emergence of new disaster risks and reducing existing ones. This is reflected in the National Disaster Risk Reduction Framework (2018), which was co-designed by all three levels of government with input from the private sector.

\subsubsection{Commonwealth}

The Biosecurity Act was enacted to manage biosecurity risks caused by diseases and pests entering, establishing or spreading in any part of Australian territory and thereby causing harm to human, animal or plant health, to the environment or, as a consequence, to the economy. To enact the statute, the Commonwealth relied on an array of legislative powers. Recognising that the Act presses these powers to their outer constitutional limits, and quite possibly beyond them, a 'severance' clause was included which provides that the Act is to have the effect it would have if its operation were limited to its constitutionally valid operation under any one of these alternative heads of power. To date there have been no court cases testing the constitutionality of the Act, even though its constitutionality is in some respects questionable (Aroney 2020: 14).

The Act empowers the Commonwealth Chief Medical Officer (CMO) to issue 'biosecurity control orders' in respect of persons exposed to 'listed' diseases. Recognising the federal context, the CMO must first consult with the state and territory chief health officers (CHOs) before doing so. Biosecurity control orders can require a person to provide contact information, report signs or symptoms, remain confined to his or her place of residence, wear particular clothing or equipment, undergo decontamination, undergo examination, provide body samples, or receive vaccination, treatment or medication.

The Biosecurity Act has been described as 'shift[ing] the constitutional boundaries between the Commonwealth and States with respect to civil emergencies' (Lee 2018: 170) and as 'an unprecedented expansion of power by the federal executive' (Brenker 2020), particularly because it encroaches on areas of regulation which would usually be within the states' domain and because Parliament has delegated to the executive branch the power to legislate and override pre-existing legislation. Possibly for these reasons, the powers available under the Biosecurity Act have been exercised sparingly and only in relation to matters generally outside of the states' areas of primary responsibility or control (see Section 4.2). 


\subsubsection{States and territories}

The states and territories have passed general emergency management laws that confer an array of extraordinary powers on public officials following the declaration of a state of emergency. Of special relevance to the Covid-19 crisis is that Public Health Acts in each jurisdiction allow for the declaration of a state of public health emergency, triggering specific emergency powers that can be exercised following such a declaration. In some jurisdictions (Queensland, Victoria prior to August 2020, and the two territories), these powers have been exercised exclusively by their respective CHOs. In the largest jurisdiction, NSW, it is the responsible minister who issues public health orders directly, while in three other states (Western Australia, Tasmania, and South Australia), the responsibility to exercise emergency powers is shared between the public health authorities and the general emergency authorities, giving rise to risks of administrative overlap.

The powers exercisable by the CHOs are extensive. They include powers to detain or restrict the movement of persons; restrict contact between persons; prevent entry into the jurisdiction; close any premises; enter any premises without a warrant; search for and seize anything; subject persons and places to decontamination procedures; direct persons to undergo medical observations, examinations or treatments; direct the destruction of any substance or thing; and issue any other directions considered reasonably necessary to protect public health.

\subsection{Rolling out measures to contain the pandemic}

Having conferred most of the necessary powers by legislation, the Australian parliaments played a largely passive role during the Covid-19 crisis. The bulk of the decision-making was undertaken by the executive and administrative branches of government, particularly by public health officials. Most intergovernmental coordination was executive-led, principally through the conversion of the preexisting COAG into the newly minted National Cabinet, which met frequently throughout the crisis. The National Cabinet generally exhibited a notable degree of unity when compared with the often fractious intergovernmental relationships that tended to characterise COAG. The Prime Minister exercised leadership but appeared most often to have sought to develop policy responses by consensus on the basis of shared expert advice. This allowed each jurisdiction to tailor its particular measures to its specific conditions, including in addressing some residual disagreement over policy goals and means. Through these mechanisms, the Prime Minister brokered what may prove to be an enduring change to the system of intergovernmental relations in Australia, even if the underlying political and fiscal tensions will remain and could become more apparent as time goes by.

\subsubsection{Taking the initiative}

On 21 January 2020, after undertaking the required consultations with his state and territory counterparts, the then CMO, Dr Brendan Murphy, determined 
that the 'human coronavirus with pandemic potential' was a listed human disease due to its communicable nature and its potential to cause significant harm to human health. This determination activated an array of powers under the Biosecurity Act. Two days later, Australian federal biosecurity officials began screening arrivals on flights from Wuhan, China, seven days before Covid-19 was declared a pandemic by the World Health Organisation. Another two days later, Australia recorded its first case.

On 1 February 2020, the Commonwealth government required returning citizens who had been in mainland China to self-quarantine for 14 days, and closed the border to all foreign nationals arriving from that country. The same rules were soon applied to persons who had been in Iran, South Korea, and Italy. During this time, the Australian states and territories initiated testing and contact-tracing regimes, while hospital, intensive care, and ventilator capacities were ramped up across the country. From 16 March, all travellers arriving in Australia from any destination were required to self-isolate for 14 days, and on 20 March the national border was entirely closed to non-residents and noncitizens. These measures were supplemented by a declaration by the GovernorGeneral on 18 March that a human biosecurity emergency existed with respect to Covid-19, triggering additional powers under the Biosecurity Act. On the same day, the federal Minister for Health used these additional powers to prevent international cruise ships from entering Australian ports except in specific circumstances.

These and other measures limited the initial spread of the disease, such that of the 300 cases identified by mid-March 2020, most were returning travellers. However, towards the end of that month, as instances of community transmission increased and national case numbers doubled every three to four days, the Commonwealth, states, and territories agreed to a nationally coordinated lockdown in which indoor and outdoor gatherings were restricted to two persons, with only limited exceptions. Several states and territories also introduced hard border closures and restrictions on travel. These latter policies resulted in a significant 'flattening of the curve' that was evident by early April. This trend continued into early June, with daily cases declining to less than 10 new cases per day, compared to a high of 460 daily cases on 28 March. The states and territories thereafter eased internal restrictions, but several maintained their respective state border closures.

Australia's relative success in controlling the spread of the virus occurred despite notable administrative failures, including the disembarkation of some 2,700 passengers from the Ruby Princess cruise liner in Sydney on 19 March 2020 without undergoing quarantine (Walker 2020). From early June, a second wave of infections became apparent, peaking in late July and early August at a high of 721 cases on 30 July. The vast bulk of these new cases were concentrated in the city of Melbourne due to another policy failure, this time involving the use of poorly trained private security guards to monitor the state's hotel quarantine system. 
The Victorian Government initially responded to the second wave through localised lockdowns focused on particular infection clusters in Melbourne and elsewhere, but these measures were not effective and in early August 2020 movement restrictions were implemented throughout the state, with even more severe restrictions imposed in Melbourne, including a controversial nightly curfew. These measures reduced the number of daily cases substantially, such that by mid-November no new cases had been reported for the previous 10 days (Department of Health and Human Services (Vic) 2020). During this period the Victorian Government had relaxed restrictions only very cautiously, giving rise to considerable controversy within the state as well as disagreements with both the Prime Minister and the Lord Mayor of the City of Melbourne.

The Australian Government initially framed its policy response around the goal of flattening the curve (Department of Health 2020b), based on models aimed at suppressing the virus in order to maintain health-care capacity (Moss et al. 2020). Some argued, however, that Australia should aim to eliminate the virus altogether, calling for an 8 - to 12 -week shutdown. Others responded that a sustained lockdown would have detrimental effects not only on the economy but on mental health as well as the diagnosis and treatment of other serious diseases, many of them more lethal than Covid-19. There was also debate about the effectiveness of particular measures, such as lockdowns, border closures and masking (Chaudhry et al. 2020; Hopman and Mehtar 2020), which gave rise to competing petitions by medical experts about what should be done.

Although the Australian response was relatively well coordinated between jurisdictions, differing assessments of the relative importance of these factors in the light of differing understandings of appropriate policy responses were at the heart of policy disagreements between the Commonwealth and the states and among the states themselves. The argument advanced by the Commonwealth's Deputy CMO that eradication was, in any case, an unrealistic goal (Coatsworth 2020) seemed to be vindicated as the second wave enveloped the State of Victoria through the winter months.

On 18 February 2020, the Commonwealth issued an emergency response plan for the Covid-19 pandemic, setting out a national approach designed to guide the Australian health sector's response to the pandemic (Department of Health 2020a). The plan, among other things, was meant to enable the state and Territory health systems to provide the highest quality medical care and to guide the efficient allocation and use of resources. Among its stated aims was to develop a whole-of-government framework at Commonwealth, state, territory, and local levels that protects Australia's social functioning and economy and minimises the outbreak's impact on the health of Australians. The plan was specific as to the particular responsibilities of the Commonwealth and the states and territories, and indicated several responsibilities to be undertaken jointly.

As noted, at a meeting of COAG on 13 March 2020, the Commonwealth, state, and territory governments agreed to establish a new National Cabinet, consisting of the Prime Minister, Premiers and Chief Ministers, which would 
meet at least weekly to coordinate the country's response to Covid-19. The Prime Minister sought to constitute the new body as a Cabinet Office Policy Committee operating in accordance with the conventions of the Commonwealth cabinet, among them the guiding principles of collective responsibility, solidarity, and confidentiality. The body is not a 'cabinet' in the ordinary sense of the word, however, because its members are not collectively responsible to the one parliament but individually responsible to their respective parliaments, and it is not clear how the usual conventions of cabinet responsibility, solidarity, and confidentiality could apply to it. Its success has depended on the commitment of the Prime Minister, Premiers, and Chief Ministers and their willingness to implement the National Cabinet's collective decisions within their respective jurisdictions. Despite its general effectiveness, considerable debate attended its unique and novel features and the likelihood of its continued operation once the crisis has passed (see Section 16.4.5).

\subsubsection{Commonwealth action}

The Commonwealth's actions fall into three categories: firstly, the leading role it took in coordinating government responses to the crisis; secondly, its primary fiscal role in implementing economic stimulus packages and providing additional funding to the states and territories to meet the needs of the emergency; and, thirdly, its attention to matters falling specifically within its responsibilities under the Constitution. As noted, although the powers available to the Commonwealth under the Biosecurity Act are vast, they were used only in relation to matters broadly of national interest or concern, including overseas travel, retail outlets at international airports, remote indigenous communities, cruise ships, the 'Covid Safe' app, and the distribution of 'essential goods' such as face masks and hand sanitiser. The Commonwealth parliament had a mostly passive role during the crisis. During a one-day sitting on 23 March 2020, however, it passed an Omnibus Bill approving, among other things, a stimulus package of AUD 66 billion and an amendment to the Biosecurity Act enabling biosecurity control orders to be issued by public service employees in the Health Department.

The Commonwealth's financial assistance measures included an additional fixed 'Coronavirus Supplement' payment added onto existing welfare scheme payments, more relaxed income and assets test standards for the existing JobSeeker scheme (welfare payments for unemployed job hunters), introduction of a new JobKeeper wage subsidy to keep at-risk employees from losing their jobs and a JobMaker Hiring Credit scheme to incentivise businesses in employing additional young employees, as well as certain measures aimed at preventing termination of commercial leases and relieving company directors from personal liability for insolvent trading by their companies.

Many of the deaths from Covid-19 in Australia were associated with agedcare facilities. Under the Constitution, responsibility for such matters ordinarily 
falls to the states and territories, but over time the Commonwealth has become increasingly responsible for their funding and regulation (Tracey and Briggs 2019: 42-46). The Commonwealth provided guidance and additional funding to aged-care facilities throughout the Covid-19 crisis (Pagone and Briggs 2020: 4-6). However, a recent Royal Commission report identified significant shortfalls in the system, including conflicting advice provided by Commonwealth and NSW officials in relation to the movement into hospital of infected aged-care residents and failures to properly manage the outbreak of infections in Victorian aged-care facilities. The Royal Commission recommended the establishment of a national aged-care advisory body, promulgation of clear protocols regarding Commonwealth and state responsibilities, and appointment of trained infectioncontrol officers in elderly care facilities (Pagone and Briggs 2020). These recommendations were accepted by the Commonwealth (Colbeck 2020).

The Commonwealth also provided support to the states and territories through the provision of large numbers of Australian Defence Force (ADF) personnel to help with quarantine compliance, contact tracing, border controls, and similar tasks. This became a point of political controversy following Victoria's bungling of its hotel quarantine program when it emerged that the Prime Minister's offers of ADF assistance had been ignored or refused by the Victorian Government. It was alleged that the poorly trained security guards employed to monitor hotel quarantine had engaged in sexual relations with persons under quarantine, contributing to the second wave of infections that required a second shutdown of the state. The scandal led to the resignation of the Minister for Health. The Victorian Government established a board of inquiry to investigate the actions of government agencies, hotel operators, and private contractors (Coate 2020).

\subsubsection{State and territory action}

The state and territory emergency management and public health laws allow declarations of emergency to be made and enable emergency powers to be exercised. These powers have been described as 'both extensive and highly elastic': they include the power to compel individuals in a broad range of ways and confer wide discretion on the relevant decision-maker (Carter 2020: 117, 127). In 2020, all jurisdictions except NSW declared a public health emergency, while Tasmania, Western Australia, South Australia, and Victoria also declared a state of emergency under their emergency management laws. In Victoria, a state of disaster declaration was not made until 2 August 2020, at which point it was deemed necessary as a response to a uniquely aggressive second wave of infections.

The particular measures taken by each state and territory were formulated within the National Cabinet framework. The latter enabled each jurisdiction to implement agreed policies in ways considered suitable to local conditions and to adopt specific measures to respond to particular challenges. These measures were ramped up when Covid-19 infections increased in March 2020, relaxed after 
they declined in April and May, ramped up again as infections increased, especially in Victoria, in July and August, and gradually relaxed in September and October. At the height of the second wave of infections, restrictions in Victoria were much more extensive than those in other states. By mid-November, in Queensland there were only relatively minor restrictions on gatherings, businesses and other activities and travel within the state, whereas in Victoria masks still had to be worn in public and gatherings in homes remained restricted (Victorian Government 2020).

All states except Victoria imposed strict border controls. The extent of these restrictions varied over time, ranging from 14-day quarantine requirements and targeted restrictions on travel by infected persons from particular hotspots to blanket bans with only minor exemptions. In response to prolonged border closures in states such as Western Australia, Commonwealth government ministers emphasised the importance of inter-state trade for the national economy, with the NSW Premier criticising the Queensland Government for imposing unrealistic conditions on the reopening of its borders. Apex business bodies criticised the "patchwork of inconsistent state and territory-based rules that ignore the reality of the way small and large businesses operate across borders and Australians live their lives' (Ferguson et al. 2020). Similar tensions emerged about the maintenance of strict lockdown requirements in Victoria for indefinitely long periods without a sufficiently transparent set of criteria and timetable for their relaxation (Wells et al. 2020). In response to criticism by the Commonwealth Health Minister, the Victorian Premier argued that Victorian health officers and politicians have a better understanding of conditions within the state. However, similar complaints were made by local government leaders in regional Victoria, who expressed concerns about the state government's failure to understand or take into consideration conditions in regional areas.

The organisational structure of the state and territory health departments was also significant. In NSW, a decentralised system of local area health districts enabled the state to implement a relatively effective system of contact tracing from the outset, whereas in Victoria a highly centralised health department had to build contact-tracing capacity from a very limited local base, with much less success. The devolved public health units in NSW already had well-established links with local health providers and community leaders and were in a better position to understand the local social and cultural factors that determine the spread of the disease and the human response to government requirements (Bennett 2020).

The border restrictions gave rise to legal challenges on the basis that they contravene the constitutional requirement that inter-state 'trade, commerce and intercourse' must be 'absolutely free' (Constitution, section 92). This protection was seen by the framers of the Constitution as an essential element of the federal compact between the states (Aroney et al. 2015: 310-13). The expression of this protection in such sweeping and unqualified terms - 'absolutely free' - is extraordinary, especially given the otherwise precise and often technical language used in the Constitution. However, the High Court has found ways to 
restrict the apparently unlimited scope of section 92 (Cole v. Whitfield (1988) 165 CLR 360). The Court has accepted that laws can validly impose burdens on both trade and commerce and personal movement across state borders provided that such laws pursue a legitimate objective in a proportionate manner (Cunliffe v. Commonwealth (1994) 182 CLR 272).

The critical question is how to determine whether a law is proportionate, for such questions require the Court to weigh the competing public interests. Part of the reason why it has been difficult to predict the result of the constitutional challenges to the state border closures is that the exact test to be applied to determine their validity is not entirely settled. This uncertainty is then compounded by the complexity of the issues raised by government attempts to limit or prevent the spread of Covid-19 in the community.

The one sustained challenge to the border closures was brought by mining billionaire Clive Palmer against the border regime implemented by the State of Western Australia. Although Palmer wished to travel from Queensland to Western Australia to manage his Perth-based business, he did not classify as an exempt traveller under the Western Australia Directions and therefore was prohibited from entry into the state. His case depended on expert evidence concerning the reasonable need for and efficacy of the closure of the state border. On 25 August 2020, a Federal Court judge found that border controls are an accepted and effective component of the public health response to the control of infectious disease outbreaks. Notably, this finding was based on evidence provided by epidemiological and public health experts and did not take into consideration the economic, social, and individual impacts of the border closures, even though these factors could be relevant to a determination of whether the measures were reasonably proportionate.

However, on 6 November the High Court resolved the case on what may be called technical grounds (Palmer $\mathcal{E}$ Anor $v$. The State of Western Australia $\mathcal{E}$ Anor [2020] HCATrans 180). It determined that the relevant sections of the statute under which the Directions had been made complied with the requirements of section 92 of the Constitution and that the question of whether the Directions were validly authorised by those sections did not raise a constitutional question.

\subsubsection{Local government action}

As noted, local government is a creature of the states and its responsibilities are relatively limited. However, a role for local government was envisaged by the Commonwealth's emergency response plan (Department of Health 2020a: 2.4, 4.2.1). According to this plan, local government responsibilities are mostly supportive rather than regulative, although they do include representing the interests of local communities in broader planning processes and providing feedback on the effectiveness of government activities. Some local government researchers observed that these functions go beyond anything that local government has 
recently been expected to perform (Zierke 2020: 3). However, it can also be noted that several of them are already recognised functions of local government in the various state local government Acts.

The governments of Australia's three most populous states (NSW, Victoria, and Queensland) established dedicated websites with information and guidance for local governments. A survey of initiatives taken by the local councils of Australia's three most populous cities (Sydney, Melbourne, and Brisbane) located in these three states suggests they sought to communicate health-related information from their respective health departments; assist state authorities in contact tracing and encouraging testing and wearing of masks; implement measures to support businesses and facilitate economic recovery; and support physical and mental health and maintain community connection (City of Melbourne 2020; City of Sydney 2020; Queensland Government 2020).

However, this is to focus attention on the largest and most urbanised population centres in the three largest states. In the local government field, questions are being asked about whether government handling of the crisis illustrates problems associated with excessive centralisation of decision-making at state and federal levels vis-à-vis local government, especially in remote regions. A persistent criticism of state government lockdowns and border closures has been that they have tended to adopt state-wide policies focused on containment of the virus within large cities without sufficient adaptability or flexibility for regional and remote areas where the incidence of the virus is minimal or non-existent. This is partly a consequence of the perceived need for urgent and extreme action, but it is also an artefact of a centralised decision-making process driven by urban-based experts. It is an open question whether local governments in regional and remote areas would have made the same policy decisions for their particular communities based on the same information about the incidence, spread, and impact of the virus available to decision-makers at a state level.

Other issues that particularly affected local governments were pressures placed on local recreational areas and parks and local-government-managed caravan parks, which were under increased pressure during lockdowns and as a result of border closures (Zierke 2020: 8-11). In the October 2020 budget, the Commonwealth expanded the existing Local Roads and Community Infrastructure program with an additional AUD 1 billion for councils to immediately upgrade local roads, footpaths, and street lighting, complemented by the availability of an AUD 1.2 billion wage subsidy programme for trainees and apprentices and several other funding initiatives.

\subsubsection{Intergovernmental relations}

Most of Australia's responses to the Covid-19 crisis took place in the context of a coordinated all-of-government approach led by the Commonwealth but cooperatively agreed to by the states and territories within the newly developed National Cabinet process. While each jurisdiction exercised its constitutional 
powers independently and with important dimensions of diversity, this occurred within an agreed framework.

In making its risk assessments and policy decisions, the National Cabinet was informed primarily by an array of expert bodies that developed guidelines intended to provide nationally consistent advice to public health units concerning case management and contact tracing (Communicable Diseases Network Australia 2020). Other bodies were responsible for identifying issues to be addressed, assessing the resources and capabilities required to mitigate impacts, and coordinating activities with stakeholders in sectors such as education, public safety and policing, banking, transport, food, and agriculture in the development of public-private partnerships for anticipating and mitigating the social and economic effects of the pandemic (Department of Home Affairs (Cth) 2020).

On 29 May 2020, the National Cabinet took the further step of agreeing to the formation of the National Federation Reform Council (NFRC) and the cessation of COAG as the primary forum of intergovernmental relations (Department of the Prime Minister and Cabinet 2020). The Prime Minister claimed that the NFRC would change the way in which the Commonwealth, states, and territories address emergent issues requiring reform, with the intention that the new model would streamline processes and thus enable improved collaboration, communication, and effectiveness. A degree of continuity would be preserved, however, with particular COAG taskforces continuing to address their assigned matters.

By the end of 2020, the National Cabinet continued to function as the apex intergovernmental body coordinating the Commonwealth, state, and Territory responses to the crisis. The outcomes of its meeting of 23 October 2020 illustrate its capacity to facilitate cooperative federalism while also reflecting underlying tensions. On the one hand, the Commonwealth and seven of the states and territories agreed to a new framework for 'national reopening' (i.e., relaxation of restrictions), but with the notable disagreement of Western Australia, which was unwilling to 'cede control' over its border (McNeill 2020). On the other hand, all nine jurisdictions accepted the recommendations of a review of the old COAG councils and ministerial forums which was highly critical of inefficient and often ineffective, convoluted, and over-bureaucratised arrangements (Conran 2020: 2).

Noting the way in which the National Cabinet processes had enabled ministers and chief executive officers to cut through issues to agree on nationally coordinated responses, the report recommended disbanding numerous ministerial forums and rationalising others, greater ministerial control over agendas, and substantial reductions in administrative staffing (Conran 2020: 5-8). The implications of these and other changes may prove significant. To what extent do they signal a lasting change in Australian intergovernmental relations?

While described as a 'council', COAG was more in the nature of an occasional summit meeting of Australia's heads of government. It never 'existed' as a standing body established constitutionally or by legislation. Instead, it was an intermittent 
forum in which Australian political leaders met to discuss and adopt coordinated policies on issues of public importance. Its meetings were infrequent, fleeting, bureaucratised, and often politicised. In its early days, COAG was a collaborative body that achieved significant reforms, but its agenda and processes became increasingly dominated by the Commonwealth. At times it enabled significant intergovernmental cooperation, but it was also the site of acrimonious disagreement and contributed to 'executive federalism' in which democratic accountability and parliamentary responsibility are side-lined (Aroney 2017: 199).

Several structural features of the National Cabinet distinguish it from COAG. Firstly, while the National Cabinet plans to continue meeting monthly after Covid-19, COAG generally met only biannually. Secondly, the membership of COAG and the National Cabinet are not identical. While the National Cabinet is composed solely of the executive heads of each state, territory, and the Commonwealth, COAG's final membership also included representation of local government through the President of the Australian Local Government Association (ALGA). Under the new arrangements it appears the ALGA will be represented only at the annual meeting of the NFRC.

Thirdly, while COAG facilitated coordination of a wide range of matters, the old intergovernmental councils and ministerial forums will be drastically reduced under the National Cabinet scheme to several of the most important, such as education, energy, environment, health and infrastructure (Conran 2020: 5). Fourthly, whereas COAG processes were highly bureaucratised, it is intended that councils and ministerial meetings will be radically streamlined (Conran 2020: 7). Fifthly, in accordance with its establishment as a Cabinet Office Policy Committee, it is proposed that National Cabinet processes will be subject to cabinet secrecy and its decisions released only if the Prime Minister decides to do so. By contrast, COAG decisions were expected to be made public within the week of their being made.

The future of the National Cabinet is unknown and difficult to predict. The underlying political conditions for cabinet solidarity are not present because its members are drawn from and responsible to different parliaments and represent competing political party platforms and interests. The potential for division and disagreement was illustrated early on when, following the National Cabinet meeting of 22 March 2020, the NSW and Victorian Premiers and the Chief Minister of the Australian Capital Territory (ACT) appeared to break ranks by recommending that parents keep their school-aged children home from school, whereas the Federal Government maintained that schools should remain open.

This need not be seen as a weakness but rather a strength of the system, for the National Cabinet deliberately identified areas of coordinated action, leaving each jurisdiction free to make its own determinations about how best to implement those decisions and what other policies might be appropriate or necessary to meet the specific conditions and needs of each locality. As Cheryl Saunders (2020: 4) has observed, disagreements among the jurisdictions 'did not detract 
from the National Cabinet as an effective, genuinely intergovernmental process, responding to an urgent public need in ways the public could trust'.

Nonetheless, as Saunders also points out, a key ongoing question is whether the National Cabinet will continue to embody a form of executive federalism, or whether ways will be found to accommodate the important roles of the state and territory parliaments and cabinets in the system of intergovernmental relations in Australia (Saunders 2020: 4). Too many reform efforts in the past have served only to underscore the 'governmentality' of the Australian system, with changes that were supposed to improve accountability to the people resulting actually in increased accountability of the states and territories to Commonwealth bureaucrats (Aroney 2010: 75, 81).

\subsubsection{Intergovernmental fiscal relations}

The Commonwealth took a lead role in providing the very substantial funding required for emergency medical supplies and economic stimulus during the crisis. Early on, on 12 March 2020, it announced an AUD 17.6 billion stimulus package to protect jobs, which was soon followed on 22 March with a second stimulus package of AUD 66 billion. In addition, at the COAG meeting of 13 March 2020 a new 50-50 shared-funding deal between the Commonwealth, states, and territories was announced to support more effective assessment, diagnosis, and treatment of people with the coronavirus. By the time of the federal budget in early October 2020, the Commonwealth had spent or committed a total of AUD 198 billion to economic stimulus and health measures. These measures are significant because, while the states and territories own and run their own public hospital systems, they are dependent upon the Commonwealth for about 50 per cent of their funding.

Despite the radical nature of the reforms associated with the newly evolving National Cabinet system, it appears that the Council on Federal Financial Relations (CFFR), which consists of the treasurers of the Commonwealth, states, and territories, will continue to play a central role. This role includes reviewing all funding agreements between the Commonwealth and the states with a view to rationalising and consolidating them, as well as acting as the 'gatekeeper' for new agreements (Conran 2020: 18, 28). The long-term implications for federal-state financial relationship remain to be seen.

\subsection{Findings and policy implications}

Governmental responses to policy crises are shaped by institutional structures and decision-making processes. In unitary states, decision-making power is constitutionally concentrated in a single locus of governmental authority, whereas in federations it is constitutionally distributed. Federations thus enable democratically accountable governance to be conducted at the relatively smaller scale as well as on a whole-of-federation basis. This allows state governments 
to be more responsive to the needs and expectations of their respective populations. However, local governments in Australia are subordinate institutions: their powers and responsibilities are dependent and derivative; they lack constitutional self-determination and their jurisdiction is determined by state legislation.

A disease like Covid-19 does not respect national, state, or local boundaries. The spread of the disease in Australia has depended on patterns of human interaction, spreading most rapidly among mobile and concentrated populations in the major cities and large towns, while having less impact in regional centres and very little in rural areas. Governmental responses were obviously needed, but the pattern of the disease required different measures at national, state, and local levels. Very restrictive measures were instituted among concentrated populations, but the application of such measures in places where the impact of the disease was minimal or non-existent may have been excessively restrictive and could have resulted in an inefficient allocation of resources. Given the need for both general coordination and localised flexibility, how well has the particular federal configuration of governmental power in Australia facilitated a policy response that achieves both of these objectives?

Australia was relatively well prepared for the Covid-19 crisis. Legislation was in place at Commonwealth, state, and territory levels, and several policy documents detailed system-wide coordinated response plans for an array of emergency situations, including an influenza pandemic. While the powers available to the Commonwealth under the Biosecurity Act are extensive, they were used sparingly and only in relation to matters generally outside of the states' areas of primary responsibility. As might have been expected, the Commonwealth was the major financier of the coordinated response, whereas most of the regulatory measures were implemented by the states and territories pursuant to their respective laws, with important administrative and policy differences in each jurisdiction.

This did not mean that the jurisdictions acted independently. Rather, their actions were coordinated by the newly minted National Cabinet. This enabled a coordinated government response, based on shared expert advice, with each government implementing particularised policies within this framework based on the specific conditions and needs of its jurisdiction. Much of it was remarkably cooperative, but there were also political disagreements and disputes between the Commonwealth and the states and territories, as well as among the states themselves.

The relative success of the National Cabinet has depended on the political goodwill of the Prime Minister, Premiers, and Chief Ministers. However, considerable debate has attended its novel features and the likelihood of its continued effective operation once the crisis has passed. The jury is still out as to whether it will facilitate genuinely improved collaboration, effectiveness, and accountability in the long term. While substantial reforms have been implemented, there are also signs that cooperation is waning and 'politics-as-usual' may be returning. 
Furthermore, while a whole-of-government approach was adopted, there are questions whether centralised decision-making at state level allowed sufficient adaptability or flexibility for regional and remote local government areas where the incidence of the virus was minimal or non-existent. Moreover, NSW's devolved public health system enabled it to implement a more effective contact-tracing regime than Victoria's more centralised system, and the exclusion of local government representation from the regular meetings of the National Cabinet was a point of contention. Nonetheless, in spite of occasional significant policy failures and administrative errors, the Australian response was remarkably effective in controlling the spread of the virus, suggesting the capacity of the Australian federal system to respond to a global crisis in a manner which is both centrally coordinated and regionally differentiated.

\section{References}

Aroney, Nicholas. 2010. 'Reinvigorating Australian Federalism', in Michael White and Aladin Rahemtula (eds), Supreme Court History Program Yearbook 2009, pp. 75-87. Brisbane: Supreme Court Library Queensland.

Aroney, Nicholas. 2017. 'Reforming Australian Federalism: The White Paper Process in Comparative Perspective', in Mark Bruerton et al. (eds), A People's Federation, ch. 12. Annandale: The Federation Press.

Aroney, Nicholas. 2020. 'What Remains of the Engineers Case? A Centenary Appraisal', Australian Law Journal, 94: 684-98.

Aroney, Nicholas, et al. 2015. The Constitution of the Commonwealth of Australia: History, Principle and Interpretation. Melbourne: Cambridge University Press.

Bennett, Catherine. 2020. 'Where Did Victoria Go So Wrong with Contact Tracing and Have They Fixed It?', The Conversation, 13 October, https://theconversation.com/ where-did-victoria-go-so-wrong-with-contact-tracing-and-have-they-fixed-it-147993 (accessed on 23 November 2020).

Brenker, Stephanie. 2020. 'An Executive Grab for Power during COVID-19?', Australian Public Law Online, May 13, https://auspublaw.org/2020/05/an-executive-grab-forpower-during-covid-19/ (accessed on 15 August 2020).

Carter, David J. 2020. 'The Use of Coercive Public Health and Human Biosecurity Law in Australia: An Empirical Analysis', University of New South Wales Law Journal, 43(1): 117-54.

Chaudhry, Rabail et al. 2020. 'A Country Level Analysis Measuring the Impact of Government Actions, Country Preparedness and Socioeconomic Factors on COVID-19 Mortality and Related Health Outcomes', EClinicalMedicine, 25: 100464.

City of Melbourne. 2020. 'Coronavirus (COVID-19)', City of Melbourne, https://www. melbourne.vic.gov.au/community/health-support-services/health-services/Pages/ novel-coronavirus.aspx (accessed on 7 November 2020).

City of Sydney. 2020. 'Covid-19 pandemic', City of Sydney, https://www.cityofsydney.nsw. gov.au/covid-19 (accessed on 7 November 2020).

Coate, Jennifer. 2020. 'COVID-19 Hotel Quarantine Inquiry: Interim Report and Recommendations',Victorian Government Printer, November 6.

Coatsworth, Nick. 2020. 'Deputy Chief Medical Officer's Press Conference about COVID19 on 23 April 2020', Department of Health, April 23, https://www.health.gov.au/news/ deputy-chief-medical-officers-press-conference-about-covid-19-on-23-april-2020 (accessed on 7 November 2020). 
Colbeck, Richard. 2020. 'Government Welcomes Aged Care Royal Commission's COVID19 Report Recommendations', Media Release, October 1, https://www.health. gov.au/ministers/senator-the-hon-richard-colbeck/media/government-welcomesaged-care-royal-commissions-covid-19-report-recommendations (accessed on 7 November 2020).

Communicable Diseases Network Australia. 2020. 'Coronavirus Disease 2019 (COVID-19) CDNA National Guidelines for Public Health Units',Version 3.10, October 28.

Conran, Peter. 2020. 'Review of COAG Councils and Ministerial Forums - Report to National Cabinet', Australian Government - Department of Prime Minister and Cabinet.

Council of Australian Governments. 2011. 'National Health Reform Agreement', Council of Australian Governments, https://www.federalfinancialrelations.gov.au/content/npa/ health/_archive/national-agreement.pdf (accessed on 7 November 2020).

Department of Health (Cth). 2019. 'Australian Health Management Plan for Pandemic Influenza (AHMPPI)', Australian Government - Department of Health, https://www1. health.gov.au/internet/main/publishing.nsf/Content/ohp-ahmppi.htm (accessed on 7 November 2020).

Department of Health (Cth). 2020a. 'Australian Health Sector Emergency Response Plan for Novel Coronavirus (COVID-19)', February 18.

Department of Health (Cth). 2020b. 'Impact of COVID-19: Theoretical Modelling of How the Health System can Respond', https://www.health.gov.au/sites/default/files/ documents/2020/04/impact-of-covid-19-in-australia-ensuring-the-health-system-canrespond-presentation.pdf (accessed on 7 November 2020).

Department of Health (Cth). 2020c. 'Coronavirus (COVID-19) Current Situation and Case Numbers', https://www.health.gov.au/news/health-alerts/novel-coronavirus-2019ncov-health-alert/coronavirus-covid-19-current-situation-and-case-numbers (accessed on 17 October 2020).

Department of Health and Human Services (Vic). 2020. 'Victorian Coronavirus (COVID-19) Data',Victorian Government - Department of Health and Human Services, https://www. dhhs.vic.gov.au/victorian-coronavirus-covid-19-data (accessed on 7 November 2020).

Department of Home Affairs (Cth). 2020. 'About Emergency Management: National Coordination Mechanism', Australian Government - Department of Home Affairs, https://www.homeaffairs.gov.au/about-us/our-portfolios/emergency-management/ about-emergency-management/national-coordination-mechanism\# (accessed on 7 November 2020).

Department of the Prime Minister and Cabinet. 2020. 'COAG becomes National Cabinet', Media Release, June 2, https://www.pmc.gov.au/news-centre/government/coagbecomes-national-cabinet (accessed on 4 August 2020).

Fenna, Alan. 2020. 'Coping with COVID: An Encomium to Australian Federalism', UACES Territorial Politics, June 12, https://uacesterrpol.wordpress.com/2020/06/12/ coping-with-covid-19-an-encomium-to-australian-federalism/ (accessed on 7 November 2020).

Ferguson, Richard, Rebecca Urban and Adeshola Ore. 2020. 'Business Demands Action on Borders', The Australian, August 24, https://www.theaustralian.com.au/news/ coronavirus-australia-live-news-australia-hk-embassy-bars-kiwi-spouse-fromqueensland-return/news-story/4be362ea73f7197278c8f16666bbfdcf (accessed on 7 November 2020).

Hopman, Joost and Shaheen Mehtar. 2020. 'Country Level Analysis of COVID-19 Policies', EClinicalMedicine 25: 100500.

Lee, H. P., et al. 2018. Emergency Powers in Australia, 2nd ed. United Kingdom: Cambridge University Press. 
McNeill, Heather. 2020. 'Other Interstate Border Policies are Working to Stop COVID19, Despite WA Chief Health Officer's Advice', WA Today, October 26, https://www. watoday.com.au/national/western-australia/other-interstate-border-policies-are-workingto-stop-covid-19-despite-wa-chief-health-officer-s-advice-20201023-p5683y.html (accessed on 7 November 2020).

Moss, Robert, et al. 2020. 'Modelling the Impact of Covid-19 in Australia to Inform Transmission Reducing Measures and Health System Preparedness', https://www. medrxiv.org/content/10.1101/2020.04.07.20056184v1 (accessed on 05 March 2021).

Pagone, Tony and Lynelle Briggs. 2020. 'Aged Care and COVID-19: A Special Report', Royal Commission into Aged Care Quality and Safety, October 1.

Queensland Government. 2020. 'Border Restrictions', Queensland Government Restrictions in Queensland, https://www.qld.gov.au/health/conditions/health-alerts/ coronavirus-covid-19/current-status/public-health-directions/border-restrictions (accessed on 10 October 2020).

Saunders, Cheryl. 2020. 'A New Federalism? The Role and Future of the National Cabinet'. Governing During Crises Policy Brief, University of Melbourne.

Tracey, Richard and Lynelle Briggs. 2019. 'Interim Report: Neglect, Volume 1', Royal Commission into Aged Care Quality and Safety, October 31.

Victorian Government. 2020. 'Coronavirus (COVID-19) Reopening Roadmap: Third Step - Victoria', https://www.coronavirus.vic.gov.au/coronavirus-covid-19-reopeningroadmap-third-step-victoria (accessed on 10 November 2020).

Walker, Brett. 2020. 'Report of the Special Commission of Inquiry into the Ruby Princess', Special Commission of Inquiry into the Ruby Princess, August 14.

Wells, Geoffrey et al. 2020. 'Open Letter - Alternative Response to COVID-19 for Victoria', Australian Doctors Federation, August 31, https://ausdoctorsfederation.org. au/2020/09/03/open-letter-alternative-response-to-covid-19-for-victoria/ (accessed on 7 November 2020).

Zierke, Merle. 2020. 'Covid-19 and Local Government in Australia', Briefing for LGiU Australia, April 1. 